\title{
Cellular markers indicative of ozone stress on bioindicator plants growing in a tropical environment
}

\author{
Edenise Segala Alves a,*, Bárbara Baêsso Moura ${ }^{a}$, Andrea Nunes Vaz Pedroso ${ }^{a}$, \\ Fernanda Tresmondi ${ }^{a}$, Silvia Rodrigues Machado ${ }^{b}$ \\ a Instituto de Botânica, Núcleo de Pesquisa em Anatomia, Caixa Postal 68041, CEP 04045-972 São Paulo, SP, Brazil \\ b Universidade Estadual Paulista, Instituto de Biociências, Departamento de Botânica, Caixa Postal 510, CEP 18618-000 Botucatu, SP, Brazil
}

\section{A R T I C L E I N F O}

\section{Article history:}

Received 5 August 2015

Received in revised form 29 February 2016

Accepted 3 March 2016

Available online 25 April 2016

\section{Keywords:}

Nicotiana tabacum

Ipomoea nil

Psidium guajava

Oxidative stress

\begin{abstract}
A B S T R A C T
Ozone $\left(\mathrm{O}_{3}\right)$ is an oxidative pollutant that causes visible foliar symptoms in sensitive plants. Importantly, cellular markers induced by physiological alterations, including oxidative burst (OB), hypersensitive response-like (HR-like) reactions, and accelerated cell senescence (ACS), precede these symptoms. Because little is known about the effects of ozone in tropical environments, we aimed to identify these cellular markers in Nicotiana tabacum, Ipomoea nil and Psidium guajava growing in an urban area of tropical Sao Paulo, Brazil, and describe the specific physiological alterations that trigger the development of visible symptoms. Cell wall wart-like protrusions, an OB cellular marker, and swelling of thylakoids and mitochondrial membranes, as well as accumulation of plastoglobuli, all markers of ACS, were cell markers common to all species studied. Cellular markers indicating HR-like reaction, as observed in the asymptomatic leaves of $N$. tabacum and I. nil, are precursors of future development of necrotic areas, featuring the visible symptoms. On the other hand, the main cause of visible symptoms in $P$. guajava appeared to be the accumulation of phenolic compounds in the mesophyll tissue, an ACS marker. Based on this line of evidence, these bioindicator plants growing in a tropical environment show the damaging effects of $\mathrm{O}_{3}$ pollution, even before visible symptoms develop. Moreover, this damage can be detected through a distinct group of cellular markers.
\end{abstract}

(c) 2016 Elsevier Ltd. All rights reserved.

\section{Introduction}

Tropospheric ozone $\left(\mathrm{O}_{3}\right)$ is a highly oxidative air pollutant that is toxic to plants worldwide (Ainsworth et al., 2012). It can cause foliar symptoms, as well as reduce growth and yield, in many agronomic and horticultural crops, deciduous trees, and conifers (Krupa et al., 2001). In broad-leaf plants, $\mathrm{O}_{3}$ stress causes visible leaf symptoms, generally described as interveinal light-green, whitish, bronze or reddish stippling on the light-exposed side of the leaf, which eventually develops into necrotic dots, spots, flecks and colored areas (Günthardt-Goerg and Vollenweider, 2007).

Abbreviations: ACS, accelerated cell senescence; GSR, global solar radiation; $\mathrm{H}_{2} \mathrm{O}_{2}$, hydrogen peroxide; HR, hypersensitive response; IAG, Institute of Astronomy, Geophysics and Atmospheric Sciences; $\mathrm{O}_{3}$, ozone; OB, oxidative burst; PCD, programed cell death; $\mathrm{RH}$, relative humidity; T, temperature; TEM, transmission electron microscope.

* Corresponding author. Tel.: +55 1150676000.

E-mail address: ealves@ibot.sp.gov.br (E.S. Alves).
Visible symptoms frequently require further validation with microscopic analysis (Günthardt-Goerg and Vollenweider, 2007), in which cellular response can be grouped into three main categories according to the physiological processes involved: (1) oxidative burst (OB); (2) hypersensitive response-like (HR-like) reactions, and ( 3 ) accelerated cell senescence (ACS) (Vollenweider et al., 2003).

$\mathrm{OB}$ is the first reaction to $\mathrm{O}_{3}$ stress. Inside the leaves, $\mathrm{O}_{3}$ reacts in aqueous solution and, along with many of the plant cell-wall phenolics, olefinic compounds, and unsaturated lipids, rapidly generates reactive oxygen species (ROS) in the apoplast (Rao and Davis, 2001; Kangasjärvi et al., 2005). Oxidative stress occurs when ROS formation exceeds antioxidant defense capacity (Wohlgemuth et al., 2002), resulting in lipid peroxidation, inactivation of proteins and DNA strand breaks, in turn, causing damage to cells and tissues (Bussotti et al., 2005; Günthardt-Goerg and Vollenweider, 2007; Faoro and Iriti, 2009). Specific cellular markers of $\mathrm{OB}$ induced by $\mathrm{O}_{3}$ include wart-like and strand-like protrusions on cell walls (Günthardt-Goerg et al., 1997), accumulation of antioxidants (Sandermann, 1996) and increased oxidation of cellular contents (Pellinen et al., 1999). 
High ozone uptake in the leaves of sensitive plants induces a wide variety of symptomatic manifestations and an equally wide-ranging variability in cell responses, both ultrastructural (Vollenweider et al., 2003) and physiological (Gravano et al., 2004).

Because of deficiencies in cellular detoxification, ROS may accumulate in the cells and elicit a "hypersensitive response (HR)", leading to the propagation of lesions and the development of visible symptoms (Iriti and Faoro, 2008). HR is a type of programed cell death (PCD) typically related to pathogen attack (Heath, 2000; Wohlgemuth et al., 2002). It consists of the collapse of the palisade mesophyll cells (Guderian, 1985) caused by the accumulation of ROS. Defensive PCD is considered HR-like when the elicitor is an abiotic stress factor (Günthardt-Goerg and Vollenweider, 2007). Typically, HR-like reactions induced by $\mathrm{O}_{3}$ occur in a restricted group of cells that die quickly due to an abrupt loss of membrane integrity (Günthardt-Goerg and Vollenweider, 2007). Microscopically, several cellular markers indicate HR-reaction, including, for example, the collapse of cell walls (Alvarez, 1998), disruption of cellular structure and incomplete degradation of cellular organelles (Fett and Jones, 1995; Fukuda, 2000), condensation of cell remnants into apoptotic-like bodies (Alvarez, 1998) and chromatin condensation and nuclear degeneration (Vollenweider et al., 2003).

Usually, the tissues surrounding HR-like reactions show structural symptoms of ACS (Pell et al., 1997). The ACS process, which is similar to natural cell senescence, has been interpreted as an accelerated process by its earlier-than-expected onset and is associated with oxidative stress caused by ROS. By their effects on leaf structure, the most important ACS markers include changes in vacuole and vacuome size (Pell et al., 1997); accumulation of secondary compounds (Schraudner et al., 1997); chloroplast disintegration, as indicated by the accumulation of plastoglobuli and their export to the vacuole (Günthardt-Goerg and Vollenweider, 2007); and the degeneration of cellular components, as evidenced by the moderate and progressive condensation of the cytoplasm and nucleus (Gahan, 1981; Fukuda, 2000).

The strategies that plants adopt to counteract oxidative stress are species-specific (Bussotti et al., 2005), as demonstrated by a variety of morphological and ultrastructural responses to $\mathrm{O}_{3}$ stress (Gravano et al., 2003). Microscopic alterations occur along with, or even precede, visible symptoms; therefore, microscopic analysis is an important tool for early detection of these symptoms (Vollenweider et al., 2003, 2013; Günthardt-Goerg and Vollenweider, 2007; Alves et al., 2011).

In tropical environments, Nicotiana tabacum 'Bel-W3' (Sant'Anna et al., 2008; Esposito et al., 2009; Pedroso and Alves, 2015), Ipomoea nil 'Scarlet O'Hara' (Ferreira et al., 2007, 2012; Alves et al., 2011; Moura and Alves, 2014) and Psidium guajava 'Paluma' (Furlan et al., 2007; Pina and Moraes, 2007; Tresmondi and Alves, 2011) are all species that exhibit visible symptoms caused by $\mathrm{O}_{3}$ stress. Using histochemistry, our previous studies detected $\mathrm{H}_{2} \mathrm{O}_{2}$ accumulation and cell death, thus demonstrating a close relationship between $\mathrm{O}_{3}$ exposure and the induction of oxidative stress that could damage the leaf tissue of these three species (Alves et al., 2011).

Nicotiana tabacum 'Bel-W3' is the best described and the most commonly used $\mathrm{O}_{3}$ indicator plant worldwide. It develops visible symptoms, such as flecking, described as small white necrotic areas caused by the death of palisade parenchyma cells, even in low concentrations of ozone (average $\mathrm{O}_{3}$ of $\sim 20 \mathrm{ppb}$ from 10:00 to 16:00 during 14 days of exposure: Heggestad, 1991; Pedroso and Alves, 2015). I. nil develops intercostal bleaching necrotic spots promoted by the HR-like reaction. These spots became visible after a 2-week exposure to ambient and $\mathrm{O}_{3}$ levels in São Paulo (average $\mathrm{O}_{3}$ of $\sim 30 \mathrm{ppb}$ from 10:00 to 16:00 during 28 days of exposure: Moura et al., 2011; Ferreira et al., 2012). In both species, necrotic spots are surrounded by chlorotic tissue. After a longer period of exposure, $P$. guajava plants exposed to $\mathrm{O}_{3}$ contamination exhibited visible symptoms, such as reddish pigmentation (average $\mathrm{O}_{3}$ levels of $\sim 18 \mathrm{ppb}$ h for $24 \mathrm{~h}$ during 40 days: Pina and Moraes, 2007), which are related to ACS and characterized by the accumulation of anthocyanins and other phenolic compounds in the leaf tissues (Tresmondi and Alves, 2011).

The cellular changes that precede visible symptoms caused by $\mathrm{O}_{3}$ in $\mathrm{N}$. tabacum include nuclear degeneration in mesophyll cells, condensation and aggregation of chromatin, invagination and apparent formation of cytoplasmic vesicles from the plasma membrane (Pasqualini et al., 2003). Otherwise, the oxidative ultrastructural changes in $I$. nil and $P$. guajava have not been previously described.

The present study, for the first time, describes the responses of a well-studied ozone bioindicator species, N. tabacum, and those of two tropical species, including an arborous species, when exposed to a tropical environment with significant concentrations of $\mathrm{O}_{3}$. We hypothesize that the cellular markers of $\mathrm{O}_{3}$ stress in I. nil and P. guajava are only partly similar to those found in N. tabacum, considering the differences between visible symptoms and the physiological responses of each species. Thus, we aimed to determine the cellular markers in N. tabacum, I. nil and P. guajava by microscopic analysis and to relate them to specific physiological processes that trigger the development of visible symptoms.

\section{Material and methods}

\subsection{Growing and maintaining plants}

N. tabacum 'Bel-W3' seeds were obtained from the State Institute for Crop Production (Landesanstalt für Pflanzenbau, Rheinstetten, Germany), and I. nil 'Scarlet O'Hara' seeds were obtained from CNSeeds Ltd (United Kingdom). N. tabacum plants were germinated and maintained according to Alves et al. (2011), and I. nil was grown following the description by Ferreira et al. (2012). The plants were transferred to field exposure when they exhibited seven $(N$. tabacum) or five (I. nil) full flushed leaves at approximately two months after sowing, following the recommendations of Verein Deutscher Ingenieure (VDI, 2003).

Clones of $P$. guajava 'Paluma' seedlings, approximately $30 \mathrm{~cm}$ high, were maintained in plastic pots ( 31 ) filled with substrate composed of Plantimax ${ }^{\mathrm{TM}}$, vermiculite and coconut shell at a ratio of $2: 2: 1$. Seedlings were kept inside a greenhouse for two weeks for acclimation before the initiation of exposure. More details about the plants are given in Alves et al. (2011).

\subsection{Field exposure}

Field exposure for N. tabacum 'Bel-W3', I. nil 'Scarlet O'Hara' and $P$. guajava 'Paluma' plants took place at the Parque Estadual das Fontes do Ipiranga (PEFI), an urban park located in the City of São Paulo (28 $38^{\prime} 08^{\prime \prime}$ S-23 $40^{\prime} 18^{\prime \prime}$ S and $46^{\circ} 36^{\prime} 48^{\prime \prime}$ W-46 $38^{\prime} 00^{\prime \prime}$ W). Additional information about the field location can be found in Alves et al. (2011).

Atmospheric concentrations of $\mathrm{O}_{3}$ were continuously measured during the experimental period with an APOA 360CE analyzer (Horiba, Japan) installed next to the plant exposure apparatus. Temperature $(\mathrm{T})$, relative humidity $(\mathrm{RH})$ and global solar radiation (GSR) were continuously recorded by a meteorological station belonging to the Institute of Astronomy, Geophysics and Atmospheric Sciences (IAG) of the University of Sao Paulo located in this same urban park. The $\mathrm{O}_{3}$ mean (considering data from 08:00 to 17:00), maximum $\mathrm{O}_{3}$ level, and SUM00 (sum of all hourly concentrations) were calculated for each period of exposure. 


\section{دانلود مقاله}

\section{http://daneshyari.com/article/4372888}

daneshyari

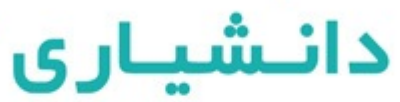

ل امكان دانلود نسخه تمام متن مقالات انگليسى ل امكان دانلود نسخه ترجمه شده مقالات \ پذيرش سفارش ترجمه تخصصى

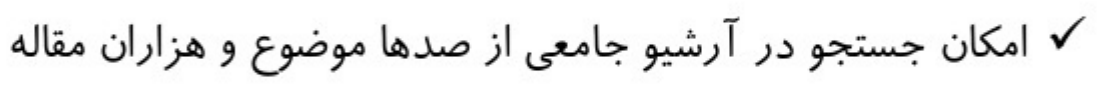
ل امكان يرداخت اينترنتى با كليه كارت هاى عضو شتاب لون

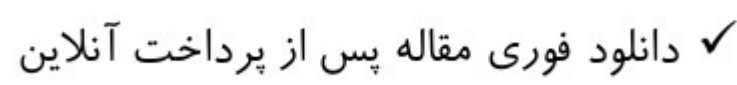

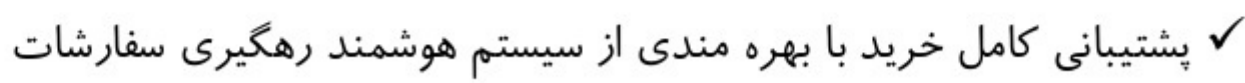

